\title{
The Effect of Quality Service and Facilities on Customer Satisfaction Trough Emotions as Intervening Variable (Case Study at Bank BRI Sharia Madiun Indonesia)
}

\author{
Shinta Maharani ${ }^{1}$, Asmak Ab Rahman ${ }^{2}$, Imas Antika Suci Ramadhani ${ }^{3}$, \\ Miftahul Ulum ${ }^{4}$, Nur Kolis ${ }^{5}$ \\ Faculty of Economics and Islamic Business, State Institute of Islamic Studies Ponorogo ${ }^{1,3}$, \\ Faculty of Shariah and Economics, Academy of Islamic Studies, University of \\ Malaya Malaysia ${ }^{2}$, Faculty of Tarbiyah and Teacher Training, State Institute of Islamic \\ Studies Ponorogo, Indonesia ${ }^{4,5}$ \\ \{maharani@iainponorogo.ac.id $\left.{ }^{1}\right\}$
}

\begin{abstract}
To compete with other banks, a banking company should maintain customer satisfaction. It's including service quality which is the most important thing to create customer satisfaction. Besides that, the completeness of the facility also affects customer satisfaction because the facility is one of physical evidence to achieve customer satisfaction. In addition to these factors, emotions could also affect customer satisfaction because emotion is an impersonal condition, covers underlying changes and behavior. Therefore companies should maintain customer emotions to have positive emotions. This study aims to determine: (1) the effect of service quality on emotions customers of BRI (Bank Rakyat Indonesia) Sharia Madiun, Indonesia (2) the effect of the completeness facilities on the customer's emotions of BRI Sharia Madiun, Indonesia. (3) The effect of service quality on customer satisfaction at BRI Sharia Madiun, Indonesia. (4) The effect of the completeness of the facility on the customer satisfaction of BRI Sharia Madiun, Indonesia. (5) Emotions influence on customer satisfaction at BRI Sharia Madiun, Indonesia. (6) The indirect effect of service quality on customer satisfaction with emotions as an intervening variable. (7) The indirect effect of facility completeness on emotions satisfaction as an intervening variable. The approach used quantitative method and use questionnaires. Path Analysis used to analyze data with 100 respondents. From the data analysis, it can be concluded that: (1) there is an influence on the quality of service on emotions. (2) There is an effect of the completeness of facilities on emotions. (3) There is an effect of service quality on authority. (4) There is an effect of the completeness of the facilities on satisfaction. (5) Emotions influence satisfaction. (6) Emotions cannot mediate between service quality and satisfaction. (7) Emotions cannot mediate between completeness of facility and satisfaction. The services and facilities provided by the bank are good and have met the provisions of good services. However, it should continue to be improved so customers feel comfortable and satisfied and there will be a strong relationship between the bank and the customer.
\end{abstract}


Keywords: Customer Satisfaction; Quality Service; Emotions; Intervening Variable; Facilities; BRI Sharia; Indonesia

\section{Introduction}

The globalization era of business competition increasingly sharp, both in national and international markets. The same thing happens in the banking business, the competition continues to increase. The tight business competition requires each financial institution to set a strategy on how to be champion in the existing market share. It's control to their customers who have remained with the company concerned. Two types of banks are often used for transactions by Indonesian people are Islamic banks and conventional banks. Because the majority of Indonesian people are Muslim, this opportunity makes Islamic banks increasingly in demand by community and continues to experience a significant increase from day to day. The rapid development makes conventional banks also establish their Islamic units. Like the BRI bank that participated in establishing a sharia unit; BRI Sharia Bank. Both in terms of quality and quantity of adequate human resources must support the development, however, in reality, many things indicate resources. Employee who has been involved in Islamic financial institutions, they have neither sufficient experience nor knowledge in Islamic banking in practice. This condition greatly affects to productivity and professionalism of banking performance in bank sharia in Indonesia. The main key that should be considered by companies in retaining their customers is to prioritize their customer satisfaction. It's the feeling that buyers feel company performance, meets their expectations. However, from the perspective of consumer behavior, 'Customer Satisfaction' then becomes something complex. Behavior after purchase will lead to a satisfied or dissatisfied to the consumer, and then customer satisfaction is a function of the buyer's expectations of the product or service with perceived performance [1].

In the banking world, customer satisfaction is the main factor that determines customers would not move to other companies. Satisfaction is the main goal that should be achieved by every company, because if customers satisfied with company performance, then it would be added value for the company. One thing that companies could do to maintain customer satisfaction is to conduct quality improvement, both in terms of service and completeness of facilities, it should be tailored to customer needs. An important factor that supports customer satisfaction is service quality. Quality of service contributes constantly to customer satisfaction itself. Islamic Banking in Indonesia should be able to have competitiveness to attract customers by providing competitive offers and providing satisfaction in terms of service. In this case, emotional factors are one thing that drives customers to achieve satisfaction as expected. After, the researcher observation, information is obtained that the services and facilities are in BRI Sharia Madiun Indonesia has been categorized as good. But after tracing through interviews with several customers at BRI sharia Madiun Indonesia, services and facilities provided by banks have not been able to meet customer desires. In BRI Sharia Madiun Indonesia, the queue is quite long, especially for the customer service section, because there is only one customer service [2]. While the physical facilities at the bank have been categorized well, however for service facilities such as internet banking and mobile banking still often experience trouble, so that customers find it difficult to conduct transactions and they should come directly to the bank if they want to make transaction [3].

The majority of customers of BRI sharia Madiun Indonesia, put their funds in deposits and savings, in this case, it can be ensured that customer wants the satisfaction obtained from the bank both from the facilities and from the services provided. One of the factors that cause 
customers to feel dissatisfied is due to their emotional encouragement. The customer does not yet have a positive emotion towards the services and facilities used at the BRI sharia Madiun, Indonesia. This shown based on the interview results with customers BRI sharia Madiun Indonesia, who are still complaining after experiencing services and use bank facilities. They feel the service and facilities are not meeting their expectations, so they have negative or bad emotions towards the bank, they do not get satisfaction [4]. Therefore and the bank should ensure that customers feel cared for and concerned with their needs and desires. Thus the customer will not move to another bank. Good service quality is the most important thing needed to create customer satisfaction. According to M. Nur Rianto, the measurement of service quality is not only determined by the parties who serve (the company), but it is also determined by the party being served based on their expectations in meeting satisfaction. Furthermore, facilities are also one of the important things in creating customer satisfaction.

\section{Theory}

The customer is the main priority that should be considered by the company because if the customer ignored, it would fail the sale of bank products or services so that the bank's profitability would be decrease. According to Nasution as quoted in a journal written by Tetty Yuliaty stated that satisfaction is shown by the feel of service quality and it's characterized by a positive attitude towards employees and a desire to repeat buyers [5]. Nowadays customers are increasingly critical of bank facilities; condition of the building, waiting room, parking lot, security. In addition to these facilities, facilities are needed by customers to provide convenience in banking transactions; transfer between accounts, mobile banking, SMS banking, internet banking, and cash withdrawals through ATMs. According to Wahyuningtyas facilities are all things that could facilitate in implementation of a business [6].

In another sense, it could be said that the facility is one bridge achievement of a desire. Banks which have complete facilities would make customers more comfortable and feel safe when making transactions with these banks. This comfort would cause satisfaction. The completeness of the facility is one of the physical evidence used to achieve customer satisfaction. In addition to the factors mentioned above, one other factor that also influences satisfaction is emotional factors. Emotion is a feeling of affection that could involve physiological humility, conscious experience, and expression of behavior. Emotions could be formulated as an aroused state of satisfactions, including changes that are realized, which are profound and behavioral [7].

Therefore, companies should pay special attention to customer emotions and try to influence customers to have positive emotions. With this effort, it is expected that their thoughts and behavior towards the company, products, and services offered will be positive too [8]. in determining the level of customer satisfaction, there are five main factors should be considered by the company; product quality, service quality, emotions, price, cost [9]. Therefore the bank should be able to provide services and facilities by what is needed by the customer.

\section{Methodology}


The variables in this study are exogenous variables and endogenous variables. Exogenous variables are influencing variables, while endogenous variables are influenced by variables. [10]. Endogenous variables in this study are customer satisfaction and emotional factors as intermediary variables. Exogenous Variables in this research are service quality and facility completeness. Thus, this is a research design, as shown in the figure:

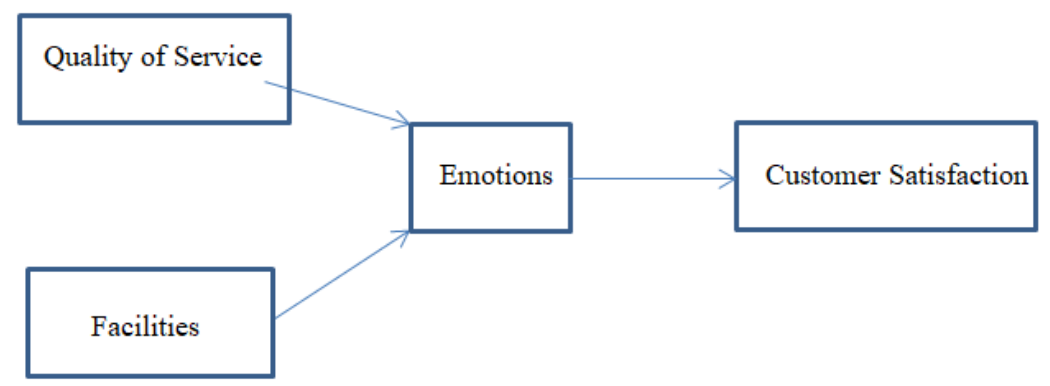

Fig. 1. Framework

The scheme of the relationship between variables $\mathrm{X}$ and $\mathrm{Y}$ description:

a. XI : Quality of Service

b. X2 : Facilities

c. $\mathrm{Z}$ : Emotions

d. Y : Customer Satisfaction

\section{Result and Discussion}

Table 1. Gender

\begin{tabular}{ccccc}
\hline & Frequency & Percent & Valid Percent & Cumulative Percent \\
\hline Valid Male & 32 & 32.0 & 32.0 & 32.0 \\
Female & 68 & 68.0 & 68.0 & 100.0 \\
Total & 100 & 100.0 & 100.0 & \\
\hline \multicolumn{5}{c}{ Source: processed primary data, 2020 }
\end{tabular}

Table 2. Ages

\begin{tabular}{ccccc}
\hline & Frequency & Percent & Valid Percent & Cumulative Percent \\
\hline Valid $<20$ years & 4 & 4.0 & 4.0 & 4.0 \\
20-25 years & 47 & 47.0 & 47.0 & 51.0 \\
$>25$ years & 49 & 49.0 & 49.0 & 100.0 \\
Total & 100 & 100.0 & 100.0 & \\
\hline \multicolumn{5}{r}{ Source: Primary data processed 2020}
\end{tabular}

Source: Primary data processed, 2020

Table 3. Educations

\begin{tabular}{|c|c|c|c|c|c|}
\hline & & Frequency & Percent & Valid Percent & Cumulative Percent \\
\hline \multirow[t]{4}{*}{ Valid } & $<$ High School & 0 & 0.0 & 0.0 & 0.0 \\
\hline & High School & 77 & 77.0 & 77.0 & 77.0 \\
\hline & $>$ High School & 23 & 23.0 & 23.0 & 100.0 \\
\hline & Total & 100 & 100.0 & 100.0 & \\
\hline \multicolumn{6}{|c|}{$\begin{array}{c}\text { Source: Primary data processed, } 2020 \\
\text { Table 4. Jobs }\end{array}$} \\
\hline \multicolumn{4}{|c|}{ Frequency Percent } & Valid Percent & Cumulative Percent \\
\hline
\end{tabular}




\begin{tabular}{lcccc}
\hline Valid Civil Servants & 29 & 29.0 & 29.0 & 29.0 \\
Entrepreneurs & 47 & 47.0 & 47.0 & 66.0 \\
Farmers & 0 & 00.0 & 00.0 & 66.0 \\
Others & 34 & 34.0 & 34.0 & 100.0 \\
Total & 100 & 100.0 & 100.0 & \\
\hline
\end{tabular}

Source: Primary data processed, 2020

Table 5. Income

\begin{tabular}{ccccc}
\hline & Frequency & Percent & Valid Percent & Cumulative Percent \\
\hline Valid $<$ 1 Million & 8 & 8.0 & 8.0 & 8.0 \\
1 Million - 2 Million & 24 & 24.0 & 24.0 & 32.0 \\
$>$ 2 Million & 68 & 68.0 & 68.0 & 100.0 \\
Total & 100 & 100.0 & 100.0 & \\
\hline
\end{tabular}

Source: processed primary data, 2020 .

Table 6. Normality Test

Asym. Sig. (2 tailed) Standard Normality Remarks

$0,676>0,05 \quad$ Normal

Source: processed primary data, 2020

Table 7. Heteroscedasticity Test

\begin{tabular}{lccc}
\hline \multicolumn{1}{c}{ Variable } & \multicolumn{1}{c}{ Sig } & Standard & Description \\
\hline Service Quality & 0,319 & $>0,05$ & Heteroscedasticity Does Not Occur \\
Facility & 0,055 & $>0,05$ & Heteroscedasticity Does Not Occur
\end{tabular}

Source: processed primary data, 2020

Table 8. Multicollinearity Test

\begin{tabular}{cccccr}
\hline Variable & Tolerance & Standard Tolerance & VIF & Standard VIF & Remark \\
\hline Service Quality & 0,736 & $>0,10$ & 1,359 & $<10$ & Multicollinearity Does Not Occur \\
Facility & 0,736 & $>0,10$ & 1,359 & $<10$ & Multicollinearity Does Not Occur \\
\hline \multicolumn{5}{c}{ Source: processed primary data, 2020 }
\end{tabular}

Table 9. Multiple Regression Test Results

\begin{tabular}{lcccc}
\hline \multicolumn{1}{c}{ Variable } & Beta & t-count & Sig t & Remark \\
\hline Quality of Service & 0,335 & 3,626 & 0,000 & Significant \\
Facilities & 0,382 & 4,138 & 0,000 & Significant \\
F Count & 3,1056 & & & \\
Sig F & 0,000 & & & \\
Adjusted R Square & 0,390 & & & \\
\hline
\end{tabular}

Source: processed primary data, 2020

Table 10. Multiple Regression Test Results

\begin{tabular}{lllll}
\hline \multicolumn{1}{c}{ Variable } & \multicolumn{1}{c}{ Beta } & Calculate & Sig t & Description \\
\hline Quality of Service & 0,235 & 2,804 & 0.006 & Significant \\
Facilities & 0,279 & 3,277 & 0.001 & Significant \\
Emotion & 0,384 & 4,444 & 0.000 & Significant \\
F Count & 41,27 & & & \\
Sig F & 0,000 & & & \\
Adjusted R Square & 0,563 & \\
\hline \multicolumn{5}{c}{ Source: processed primary data, 2020 }
\end{tabular}

a. Influence of service quality on customer emotions, based on the results of the hypothesis test, it can be concluded that there is a direct influence between the qualities of service with 
emotions on BRI sharia Madiun Indonesia. It means that good service quality will affect the customer's emotions so the customer has a good perception of the Islamic bank. The services provided by BRI Sharia Madiun Indonesia; tellers providing friendly services by applying smile, regards, greetings, would affect emotions so customers will give a good perception. Customers, who treated very well and politely, would give a good rating for the teller. It would make them feel satisfied with the services provided.

b. Effect of facility on the emotions, based on the results from the hypothesis test, it could be concluded that there is a direct influence between the facility and customer's emotions at the BRI sharia Madiun, Indonesia. Bank has adequate facilities will affect the customer's emotion. The more complete of facilities provided by the bank, customer will feel happy and comfortable thereby creating satisfaction through convenience and comfort.

c. Effect of service quality on customer satisfaction, based on the results of the hypothesis test, it can be concluded that there is a direct influence between service quality with customer satisfaction. Service quality is a measure the level of service provided matches customer expectations. Quality of service could be realized through fulfillment and desire of delivery accuracy to customer expectations. If services provided in line with customer expectations, the service quality will provide a good perception. Vice versa, if service felt worse than expected, service quality will be poorly promoted. With an increase in service quality at BRI sharia Madiun Indonesia, this could affect on customer satisfaction; customers will be happy and satisfied with services provided by BRI Sharia Madiun Indonesia. This is in line with Dini Fadila's research stating that service quality has a positive and significant effect on customer satisfaction.

d. Effect of facilities on customer satisfaction, based on the results of the hypothesis test, it can be concluded that there is a direct influence between facility and customer satisfaction. Facilities are everything that makes it easier for consumers to get satisfaction. Because the form of service cannot be seen, cannot be smelled and cannot be touched, the aspect of physical appearance becomes important as a measure of service. The customer will use the sense of sight to assess the facilities that have been provided by the bank. Perception which is formed from the interaction between customers and facilities influences service quality.

e. The satisfied customer would come back because the bank concerned about customer comfort which makes BRI sharia Madiun Indonesia always crowded and filled with customers who feel satisfaction when making transactions and waiting. This is in line with research conducted by Iriana Fatmawati stating that the facility has a positive and significant effect on customer satisfaction.

f. Emotions influence on customer satisfaction, based on the results of hypothesis testing, it could be concluded that there is a direct influence between emotions and customer satisfaction at the BRI sharia Madiun Indonesia. Emotions influence positively and significantly on customer satisfaction. Emotions related to feelings and could effect on one's thinking. Emotion shapes and influences a person's judgment on something they have felt. This is in line with Endang Sulistya Rini and Yeni Absah's research which states that emotions positive and significant influence on customer satisfaction.

g. Influence of service quality on customer satisfaction through emotions as intervening variable, The path analysis results in this study indicate that regression coefficient of service quality to customer satisfaction is 0.235 while the value of quality service coefficient to customer satisfaction through emotions as an intervening variable of 0.129 which means emotions unable to intervening between service quality to customer satisfaction due to coefficient smaller than direct influence. The results showed that indirectly service quality. 
h. Effect of facility on customer satisfaction, emotions cannot mediate between facilities towards customer satisfaction. This is indicated by the regression coefficient multiplication of the completeness of facilities to satisfaction (0.382) with emotions to satisfaction (0.384) smaller than the regression coefficient of facilities to satisfaction (0.235). Based on the discussion and conclusion above, suggestions for banks, services, and facilities provided are good and have met provisions of good services. However, it should improve so customers feel comfortable and satisfied and there will be a strong relationship between bank and customer.

\section{Reference}

[1] Ajeng Utami Ikasari, "Pengaruh Nilai Pelanggan dan Kualitas Pelayanan terhadap Kepuasan Pelanggan" Diponegoro Journal Of Social and Politic, (2013), 5.

[2] Wawancara dengan Mariana, 26 februari 2019.

[3] Wawancara dengan imam suwarno, 27 februari 2019.

[4] Wawancara dengan yayuk, 26 februati 2019.

[5] Tetty Yulity,"Pengaruh Kualitas Layanan Internet Bangking dan Brand Equality Terhadap Kepuasan Nasabah Pada PT. Bank Syariah Mandiri KCP Medan Aksara,"Jurnal Manajemen dan Bisnis, 02 (Oktober 2014), 121.

[6] Wahyuningtyas, "Manajemen Fasilitas," dalam http://staffnew.uny.ac.id/upload/131414327/pengabdian/C.PDF ,(diakses pada tanggal 13 September 2018, jam 22.56).

[7] Catur Istiqo M. dan Eddy Poernomo, "Pengaruh Kualitas Pelayanan, Harga, Dan Faktor Emosional Terhadap Kepuasan Pelanggan Pada Hotel The Sun Sidoarjo,” Jurnal Bisnis Indonesia, 1 (April 2017), 78.

[8] Endang Sulistya Rini, "Analisis Penciptaan Loyalitas Melalui Pengaruh Penerapan Strategi Pemasaran Rasional, Emosional, dan Spiritual Terhadap Kepuasan Nasabah PT. Bank Sumut Syariah Cabang Utama Medan," Jurnal Studi Manajelen dan Bisnis, 1 (2015), 63.

[9] Hadi Irawan, 10 Prinsip Kepuasan Pelanggan (Jakarta: Elek media kumputindo, 2002),

[10] Sambas Ali Muhidin dan Maman Abdurahman, Analisis Korelasi, Regresi dan Jalur dalam Penelitian (Bandung: CV Pustaka Setia, 2009. 